\title{
The Canadian Math Wars
}

\author{
Egan J. Chernoff
}

Published online: 22 January 2019

(C) Ontario Institute for Educat. Studies 2019

On September 21, 2011, Michael Zwaagstra, working for the Frontier Centre for Public Policy (FCPP), released a study entitled "Math Instruction that Makes Sense ${ }^{1}$ : Defending Traditional Instruction." However, the FCPP released the report to the media via an FCPP Commentary entitled, "New Math is Failing our Students: Teaching techniques leave students without a solid foundation." As Abtahi and Barwell (this volume) note, “... public media reporting shapes the way in which the general public comprehends mathematics education, including approaches to instruction and curriculum, as well as the key stakeholders involved." The use of the term "new math" was clever, I contend, because it equated the more recent changes taking place in Canadian mathematics classrooms with the failed, dramatic overhaul of the way mathematics was taught that took place in the 1960s, which was known as new math.

Any discerning parent or guardian - those who had either heard about or perhaps even experienced firsthand the horrors of new math-immediately questioned what was happening in math class. ${ }^{2}$ Here on the Canadian prairies, new math became a staple of stories ${ }^{3}$ found in newspapers, on the radio, and on television. With all the prairie press, new math not only became a topic of discussion from coast to coast to coast but it concurrently introduced the country to the Western Initiative for Strengthening Education in Math — better known as WISE Math — who, without opposition, ${ }^{4}$ quickly became the de facto voice for the back-to-basics movement in mathematics teaching and learning in Canada.

As Abtahi and Barwell (this volume) note, "these news stories are not simply messages; they frame a structure for their audience to think with." With the sheer amount of press being garnered by WISE Math, the Saskatchewan Government soon began to have second thoughts about the new mathematics curriculum they had just introduced. In December 2011, the Saskatchewan Government ordered a review of

\footnotetext{
${ }^{1}$ It should be noted, the title and accompanying picture on the report was clearly meant as a shot across the bow of one of the most widely adopted textbooks series at the time, Math Makes Sense.

${ }^{2}$ See Wagner (this volume) for a detailed discussion of individuals interpreting their experience through known storylines in the section on Storylines and Myth.

${ }^{3}$ See both Abtahi and Barwell (this volume) and McFeetors and McGarvey (this volume) for references, discussion and analysis of the large corpus of Canadian Math Wars media material.

${ }^{4}$ See Wagner (this volume) for a detailed discussion of Barthes rhetorical devices and storylines of mathematics education in the news.
}

E. J. Chernoff $(\bowtie)$

University of Saskatchewan, Saskatoon, Canada

e-mail: egan.chernoff@usask.ca 
mathematics instruction and curriculum. Russ Marchuk and Gene Makowsky, then Saskatchewan MLA's, began the process of consulting students, parents, teachers, and administrators. In May of 2012, less than half a year later, Saskatchewan's Ministry of Education declared that the new math curriculum would not change.

Despite the conclusion that Saskatchewan's mathematics curriculum was in line with what others were doing across North America, WISE Math was further thrust into the media spotlight. In particular, two of the WISE Math founders, Anna Stokke (University of Winnipeg) and Robert Craigen (University of Manitoba), quickly became traditional media darlings. Drawing upon their perceived morally superior stance on the debate (see Abtahi and Barwell, this volume, for a further discussion on the moral dimension to the debate), circa 2012, the teaching and learning of mathematics became a national news story. Awards for their efforts would quickly follow. And, soon, other provinces entered the fray.

In 2012 and 2013, the Atlantic Provinces, Newfoundland and Nova Scotia, in particular, decided to adopt the same common curricular framework that was under fire from WISE Math. Sure enough, discovery critics shifted their ire to these provinces. Concurrently, in what you could call a win for WISE Math, Manitoba decided to make changes to their existing mathematics curriculum, which the media would quickly story as the province ditching new math for back-to-basics. Manitoba getting back-to-basics, would be picked up again by National news media just as Ontario and Alberta entered the fray.

Every 4 years, the Organisation for Economic Co-operation and Development, assesses 15-year-old students worldwide in reading, mathematics, and science via what is called PISA. ${ }^{5}$ In the 2012 assessment, which had a specific focus on mathematics, Canada dropped slightly in the standings but remained around average. ${ }^{6}$ To hear the media report on the issue, however, was quite a different story. First, we were in the midst of a national tragedy. Second, discovery math/learning (the antonym for back-to-basics) was squarely to blame. Clearly, PISA was used to fan the flames of The Canadian Math Wars. The reporting at this time got a tad hyperbolic.

In their articles, Yasukawa and Lange (this volume) discuss, respectively, that (1) issues need to be translatable into rallying cries in order to be seen as being sufficiently newsworthy and (2) how political spectacle keeps the public acquiescent. These articles in this volume, thus, nicely inform what certain prominent Canadians thought of the average PISA test scores. According to a former Deputy Prime Minister, John Manley, the PISA results should have been considered a national emergency. Similarly, other outlets reported the PISA results as a national disaster. And in quintessential Canadian political spectacle John Manley posited: "How can we be satisfied with 13th place in math when we're not satisfied with second place in hockey?" Statements such as these began to be tempered when the other side of the debate finally entered the conversation.

It should be noted, much of the original clout originally associated with WISE Math — clout subsequently cemented by the reporting by the media of the PISA results - came from their online petition. In a similar vein, circa 2014, Nhung Tran-Davies, Md began a back-to-basics petition in Alberta and retired school teacher Teresa Murray began her, similarly themed, petition in Ontario (and, later, Tara Houle in British Columbia). In Alberta, Dr. Tran-Davies had amassed enough signatures that the door of then Education Minister swung open for her to enter.

As The Canadian Math Wars made their homes in Alberta and Ontario, conversations on the topic began to shift beyond mathematics (see, again, Abtahi and Barwell for discussion on the nature of the moral dimension of Canadian news reporting on mathematics education). Case in point, David Staples, working for the Edmonton Journal, ran a 44-part series, which he called The Great Canadian Math Debate. A quick glance of the headlines shows that approximately $50 \%$ of the articles in the series use the debate over the teaching and learning of mathematics as a gateway to discussions on political parties in Alberta, Alberta

\footnotetext{
$\overline{5}$ See Yasukawa and Lange, both this volume, for discussions regarding PISA results in Australia and Norway, respectively. And Wagner (this volume) for a discussion on public interactions regarding PISA results

${ }^{6}$ See Yasukawa, this volume, for a parallel discussion of the treatment of being OECD average in Australia.
} 
Education, and the individuals involved in the former and latter. In Alberta, in 2014, The Canadian Math Wars began to be subsumed by the Canadian Culture Wars. ${ }^{7}$ The April 2014 rally against discovery mathematics, held at the Alberta legislature, removed any remaining doubt that mathematics had become a politicized issue.

In 2014, the same year a back-to-basics rally was held at the Alberta legislature, the annual meeting of the Canadian Mathematics Education Study Group (CMESG) was held in Edmonton. CMESG, a group of mathematics educators, mathematicians, and mathematics teachers that meet annually, held a panel on the debate over the teaching and learning of mathematics. The conclusion of the panel: while PISA scores, yes, had fallen, there was no crisis; and, despite what was being presented in the media, discovery math was being erroneously blamed for the non-existent crisis.

As for how this message was received by the general public in Alberta, the comments sections of the Edmonton Journal and Edmonton Sun confirmed, at least for me, why certain publications like Popular Science have turned off their comments section. As mentioned by McFeetors and McGarvey, "We suggest that as mathematics educators, we create more opportunities for conversation with the public, and parents, to create a productive space of shared understanding" (this volume). They further note, "Perhaps, we should, instead, recognize that our research has either not reached the public or has not been sufficiently informative to alter perceptions" (this volume). And although mathematics educators, currently, still need to heed the spirit found in the above comments, they have started to weigh in in recent years.

The same year that saw Ontario, Quebec, and British Columbia join Saskatchewan in keeping their current math curriculum, Alberta, like Manitoba, made some changes to their mathematics curriculum. Alberta decided to change the language in their curriculum supporting memorization of times tables (which was the hot button math topic at the time) but with the caveat that the new methods of teaching, those at the core of the debate, would not be eliminated.

Looking on the most recent years, the conversation regarding the Canadian Math Wars from 2015 to 2018 was nowhere near as fast and furious as it was from 2011 to 2014. This reporting, though, mostly takes place at the beginning of the school year now, with very little reporting taking place outside the months of September and October. For example, British Columbia introduced a new mathematics curriculum just recently, but there were no headlines running across the country as there were previously. This does not mean the conversation regarding the Canadian Math Wars has stopped, rather it has shifted, as it appears most discussions have these days, to social media. Let us look at an example.

In what I contend is WISE Math's greatest mistake, Anna Stokke wrote a report for the C. D. Howe Institute where she opined for an 80/20 split between traditional/discovery techniques. Unlike in years past, when the word of WISE Math was treated as sacrosanct by the media, Stokke and other members of WISE Math were taken to task in both traditional and social media. Sure, individuals like Staples and others, were in support of Stokke's recommendation, but this is not a surprise. On the other side, other university professors, those that had been silent for years as the one side of the debate dominated the media, finally began to speak out on when the findings of Stokke's report were released. Their main issue: the 80/20 split was not adequately grounded, which all considered ironic given the back-to-basics hardened stance that educational research is not real research. Too little, too late for the newcomers to the debate? Sure, but as many of them told me, personally, they were aware of the topic but were not interested in rolling around in the muck. Speaking of rolling around in the muck, via social media, Robert Craigen and American mathematics educator, Dan Meyer, debated Anna's 80/20 split over Twitter for a period of nearly three straight days (which you can find at the following link: www.storify.com/matthewmaddux/rcraigenvsddmeyer). Other than heated debates by heavily vested individuals on relatively obscure social media platforms, the nuances of the Canadian Math Wars still have not made their way into the general public; and, neither has the notion of a mathematics educator.

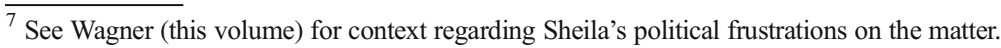


In this volume, Wagner "encourages mathematics educators to actively pursue engagements that would occasion the change of storylines". Taking him up on his offer, I wish, here, to focus on two particular storylines. First, as Wagner labeled, the mistrust of mathematics educators storyline where he goes "a step further and [makes] it personal: there is a mistrust of people who produce mathematics education research." I have always been intrigued by (and involved with) said storyline. Second, I have also always been intrigued by (and played a part in) the basic skills vs. discovery dichotomy storyline, especially the critique of caricatures. Presupposed in the former and the latter storylines, I contend, is an understanding of what a mathematics educator is and does. I further contend that this lack of general mathematics educator knowledge (e.g., If they are not mathematicians, they are not teachers, they teach future math teachers, many qualitatively conduct mathematics education research, what are they? What do they do?) may be playing a major role in shaping the public perceptions of mathematics education in the media. If conjuring a caricature of a mathematics educators is a bridge too far for the general public, then mistrust in the unfamiliar may be taken into consideration when discussing mathematics education in the media.

Albeit implicitly, informing the public about the field of mathematics education and the role of mathematics educators is found in each and every one of the articles in this special issue. For example, to reiterate McFeetors and McGarvey (this volume), mathematics educators need to create more opportunities for conversation with the public; and, further, to sufficiently inform, engage or alter perceptions with respect to the teaching and learning of mathematics. To reiterate Abtahi and Barwell (this volume), it is a challenge for our (mathematics education) community to insert our own moral values into news reporting about our field. Also found in this volume, Wagner encourages "mathematics educators to take up and construct opportunities to dialogue about mathematics education, to encourage news media representatives to set up such actual dialogues". While a special issue of an academic journal, where articles sit behind a paywall, is not the greatest start to reaching these goals, at least it is a start. One day-perhaps thanks to some future popularizer of mathematics education or some Professor for the Public Understanding of Mathematics Education - common storylines will be quite different when it comes to mathematics education and mathematics educators in the media.

Publisher's Note Springer Nature remains neutral with regard to jurisdictional claims in published maps and institutional affiliations. 